JMPF Vol. 9 No. $3: 203-212$

ISSN-p : 2088-8139

ISSN-e : 2443-2946

DOI : 10.22146/jmpf.47192

\title{
Pengukuran Kualitas Hidup Pasien Kanker Payudara di Kota Denpasar Menggunakan Instrumen EQ-5D-5L
}

\author{
Assessing Quality of Life of Breast Cancer Patients using EQ-5D-5L: a Cross-sectional Study in Denpasar, \\ Bali
}

Abdillah Mursyid, Restu Nur Hasanah Haris, Dwi Endarti ${ }^{*}$, Chairun Wiedyaningsih, Susi Ari Kristina

Fakultas Farmasi, Universitas Gadjah Mada

Submitted: 7-1-2019 Revised: 9-17--2019

Accepted: 9-26-2019

Korespondensi : Dwi Endarti: Email : endarti_apt@ugm.ac.id

\begin{abstract}
ABSTRAK
Kanker payudara adalah jenis kanker yang menduduki peringkat kedua di dunia dan termasuk salah satu penyebab terbesar kematian akibat kanker setiap tahunnya. Pengukuran kualitas hidup pada pasien kanker payudara berkontribusi dalam peningkatan terapi obat dan dapat menjadi faktor prognosis bersamaan dengan parameter medis. Penelitian ini bertujuan untuk mengukur kualitas hidup pasien kanker payudara, dan melihat pengaruhnya terhadap kualitas hidup berdasarkan karakteristik pasien kanker. Penelitian dilakukan pada 93 pasien kanker payudara. Lokasi pengambilan sampel berada di beberapa komunitas kanker payudara di Kota Denpasar yang dilakukan dalam kurun waktu 3 bulan (Januari - Maret 2019). Penelitian ini menggunakan desain cross sectional dengan menggunakan teknik Snowball sampling dengan melibatkan pasien kanker payudara di beberapa komunitas kanker di Kota Denpasar. Data kualitas hidup pasien diperoleh menggunakan instrumen generik EuroQol-5 Dimension-5 Level (EQ-5D-5L) dan konversi health utility dengan value set Indonesia. Keseluruhan data dianalisis menggunakan Independent $t$-test dan multivariate regresi linier berganda. Hasil penelitian menunjukkan domain kecemasan/depresi merupakan domain yang dilaporkan paling banyak masalah pada pasien kanker payudara (82,7\%). Nilai utility pasien kanker payudara ialah $0,821 \pm 0,123$ dan nilai VAS sebesar $74,41 \pm 11,67$. Terdapat perbedaan yang signifikan nilai utility berdasarkan karakteristik yaitu; pekerjaan $(p=0,035)$, gejala $(p=0,003)$, dan stadium kanker $(p=0,015)$ yang berpengaruh sebesar $20,5 \%$ terhadap kualitas hidup pasien kanker payudara di kota Denpasar.
\end{abstract}

Kata kunci: Kualitas hidup; Kanker Payudara; EQ-5D-5L

\section{ABSTRACT}

Breast cancer is the second most common cancer in the world and is one of the biggest causes of cancer deaths every year. Measurement of the quality of life in breast cancer patients could improve treatment and become a prognosic factor along with medical parameters for the patients. This study aims to measure the life quality of breast cancer patients and observe how it affects the life quality based on patient characteristics. The study was conducted on 93 breast cancer patients. Data were collected form patients in several breast cancer comunities in Denpasar which were carried outh within 3 months (January - March 2019). This study used a cross sectional design using a snowball sampling technique involving breast cancer patients in several cancer communities in Denpasar. The patient's life quality data was obtained using the EuroQol-5 Dimension-5 Level (EQ-5D-5L) generic instrument and conversion to health utility (utility) used the Indonesian value set. The entire data was analyzed using the independent t-test and multivariate regression. The results showed that pain/discomfort and anxiety/depression were the most dominant problem in breast cancer patients $(82,7 \%)$. The utility value of breast cancer patients was $0.821 \pm 0.123$ and the VAS value was $74.41 \pm 11.67$. There was a significant difference in utility value based on patient characteristics of occupation $(p=0.035)$, symptoms $(p=0,003)$, and cancer stadium $(p=0.015)$. Affected $20.5 \%$ of the quality of life of breast cancer patients in Denpasar city.

Keywords: Quality of life; breast cancer; EQ-5D-5L

\section{PENDAHULUAN}

Penyakit terminal adalah penyakit yang bersifat progresif dan akan berujung pada kematian. Kanker payudara merupakan salah satu penyebab kematian utama di seluruh dunia. Berdasarkan data Globocan (Global Burden of Cancer), International Agency for Research on Cancer (IARC) bahwa kanker payudara merupakan kanker dengan jumlah insidensi tertinggi kedua di dunia dengan 
jumlah 2,089 juta jiwa (11,6\% dari keseluruhan kanker) dan termasuk dalam 5 besar kanker dengan jumlah angka kematian tertinggi 627.000 jiwa (6,6\% dari keseluruhan kanker). ${ }^{1}$ Prevalensi kanker di Indonesia adalah 12/100.000 wanita, riskesdas menunjukkan prevalensi kanker payudara di Indonesia pada tahun 2013 adalah 61.682 kasus. $^{2}$

Diagnosis dan pengobatan kanker dapat memberikan dampak negatif terhadap fisik dan segi emosional dari wanita akibat dari efek samping dari pengobatan, ketakutan akan kematian, perasaan terhadap devaluasi social.,3 Efek lainnya dari pengobatan kanker payudara dapat mengakibatkan perubahan kapasitas fungsional, penutunan sensitivitas payudara perubahan cerminan diri, seperti kecemasan, depresi, dan perubahan emosi. ${ }^{4}$ Wanita dengan kanker payudara dengan pengalaman pengobatan seperti radioterapi, operasi, kemoterapi, dan terapi hormon dapat mengakibatkan kelemahan fisik, penurunan berat badan dan psikologis yang berkaitan dengan cerminan diri dan masalah seksual. ${ }^{5}$ Semua efek tersebut dapat berdampak negatif terhadap kualitas hidup dari pasien kanker payudara. ${ }^{5}$ Pengukuran kualitas hidup pasien sangat diperlukan untuk meningkatkan outcome kesehatan pasien dan mengevaluasi tatalaksana terapi. ${ }^{6}$

Pada penelitian ini, EuroQol-5 Dimensions (EQ-5D-5L) digunakan untuk mengukur kualitas hidup pasien kanker payudara. EQ-5D-5L merupakan instrumen generik yang dikembangkan oleh EuroQol Group, dan merupakan instrumen yang paling banyak dikenal dan umum digunakan untuk mengukur status kesehatan.7,8 Beberapa penelitian telah dilakukan menyebutkan bahwa kuesioner EuroQol-5 Dimensions (EQ-5D) dapat digunakan untuk mengukur kualitas hidup pasien kanker payudara. ${ }^{9,10}$ Setyowibowo (2018) telah melakukan penelitian pada pasien dengan gejala kanker payudara (sebelum adanya diagnosis) dan membandingkan dengan populasi umum. ${ }^{6}$ Rukminingsih (2018) dalam penelitiannya mengukur kualitas hidup pasien kanker payudara dengan responsif hormon yang menggunakan EQ-5D. ${ }^{6,11}$

Sepanjang pengetahuan peneliti, penelitian tentang pengukuran kualitas hidup pasien kanker payudara pada komunitas kanker di Kota Denpasar belum pernah dilakukan, sehingga penelitian tersebut perlu dilakukan. Penelitian ini bertujuan untuk mengukur kualitas hidup pasien kanker payudara, dan melihat pengaruh dari karakteristik pasien kanker payudara terhadap kualitas hidup pasien kanker payudara di Kota Denpasar.

\section{METODE}

Studi yang dilakukan berupa survei dengan rancangan cross sectional dengan menggunakan teknik snowball sampling. Penggunaan teknik sampling ini berlandaskan pada komunitas yang peneliti gunakan sebagai tempat penelitian dan agar diperoleh kemudahan dalam penggambilan data. Kriteria Inklusi studi ini meliputi pasien yang terdiagnosis kanker payudara, berdomisili di Kota Denpasar, dapat berkomunikasi aktif dengan bahasa Indonesia, dan bersedia menjadi subjek studi dengan menandatangani formulir persetujuan setelah mendapatkan penjelasan (informed consent). Kriteria Eksklusi meliputi pasien menolak untuk dilibatkan pada studi, mengalami gangguan psikis. Penelitian ini mendapatkan persetujuan etik dari Komisi Etik Fakultas Kedokteran Universitas Gadjah Mada dengan no KE/FK/0472/EC/2018.

Instrumen studi yang digunakan adalah instrument European Quality of Life-5 Dimension-5 level (EQ-5D-5L) dan Visual Analog Scale (VAS) versi bahasa Indonesia. Instrumen EuroQol-5 Dimensions atau EQ-5D-5L dapat mengukur kualitas hidup yang berhubungan dengan kesehatan. Instrumen EQ-5D-5L merupakan instrumen yang banyak digunakan sebagai sumber untuk mendapatkan informasi kualitas hidup yang berhubungan dengan kesehatan dan utilitas. EQ-5D-5L terbagi atas bagian sistem deskripsi dan EQ-Visual Analog Scale. Sistem deskripsi 
pada EQ-5D-5L terdiri atas 5 dimensi yaitu dimensi mobility (mobilitas), self care (perawatan diri), usual activity (aktivitas biasa), pain/discomfot (rasa sakit atau tidak nyaman), dan anxiety/depression (rasa cemas atau depresi) ${ }^{7}$. Nilai utility (nilai dari indeks EQ-5D) akan dikalkulasikan berdasarkan value set Indonesia yang telah dikembangkan. ${ }^{12}$

Pengambilan data dilakukan dalam kurun waktu 3 bulan, yaitu pada bulan Januari - Maret 2019. Jumlah populasi pasien kanker payudara di Provinsi Bali 1233 jiwa. ${ }^{13}$ Adapun penentuan jumlah subjek penelitian menggunakan persamaan Slovin ${ }^{14}$ sebagai berikut:

$$
n=\frac{N}{N\left(\mathrm{e}^{2}\right)+1}=\frac{1233}{1233\left(0,1^{2}\right)+1}=92,49
$$

Dengan nilai e $=10 \%$, diperoleh perhitungan jumlah sampel minimal 93 pasien. Lokasi penelitian diambil di beberapa komunitas kanker yang terletak di Kota Denpasar. Analisis data dilakukan menggunakan SPSS (version 20.0).

Variabel dependent dalam studi ini adalah nilai kualitas hidup pasien kanker payudara, dan variabel independent dalam penelitian ini adalah faktor sosiodemografi responden yang meliputi (tingkat pendidikan, pekerjaan, status pernikahan, penghasilan, asuransi, stadium kanker, gejala yang sering dialami, riwayat penyakit keluarga dan lama menderita). Analisis deskriptif digunakan dalam studi ini untuk melihat gambaran karakteristik pasien kanker payudara. Independent-t-test digunakan untuk melihat perbedaan utility pada tiap kelompok karakteristik pasien kanker payudara. Multivariate regresi linier berganda digunakan untuk melihat seberapa besar pengaruhnya terhadap kualitas hidup pasien kanker.

\section{HASIL DAN PEMBAHASAN}

Dalam penelitian ini pasien kanker payudara di provinsi Bali yang memenuhi kriteria inklusi berjumlah 93 responden. Karakteristik pasien dalam studi ini menunjukkan bahwa pasien kanker payudara didominasi pada pasien wanita dengan umur $>45$ tahun $(58,1 \%)$, dengan rerata umur pasien adalah 46,5 tahun (SD=7,25) Penelitian Chen (2018) yang dilakukan di China menyebutkan bahwa rata-rata penderita kanker payudara terjadi pada pasien dengan usia $>40$ tahun. ${ }^{5}$ Beberapa penelitian lain juga menyebutkan bahwa pasien kanker payudara didominasi pada wanita dengan usia diatas 45 tahun. ${ }^{15,16}$

Sebagian besar pasien dalam penelitian ini memiliki tingkat pendidikan sedang ( $>$ SMP). Dengan status ekonomi yang tergolong cukup tinggi ( $>4$ juta). Tingkat pendidikan dan penghasilan memiliki pengaruh dalam pandangan terhadap kanker, deteksi dini kanker payudara (breast cancer awareness). ${ }^{17}$ Sebanyak 97,8 \% pasien kanker payudara dalam penelitian ini memiliki asuransi kesehatan, sebagian besar $(76,3 \%)$ pasien kanker payudara merasakan gejala saat kanker payudara yang dilihat dari keparahan kanker, persentase pasien kanker payudara dalam penelitian ini berdasarkan stadium kanker adalah stadium I, II, III, dan IV berturut-turut 21,5\%; 47,3\%; 24,7\%, dan $6,5 \%$. Sebanyak 65 pasien $(69,3 \%)$ sudah menderita kanker payudara selama $\leq 2$ tahun. Karakteristik pasien kanker payudara (Tabel I).

Penggunaan instrumen EQ-5D-5L telah banyak dilakukan untuk mengukur HRQoL, baik pada populasi umum maupun pada pasien, pada studi ini, peneliti menggunakan value set Indonesia yang telah dikembangkan oleh peneliti lain. ${ }^{12}$ Hasil penelitian menunjukkan bahwa sebagian besar pasien kanker payudara tidak memiliki permasalahan pada beberapa domain. Domain kecemasan/depresi (82,7\%) disusul domain rasa sakit $(48,3 \%)$ merupakan domian yang paling banyak dilaporkan memiliki masalah pada pasien kanker payudara. Hal ini sejalan dengan penelitian yang telah dilakukan oleh Setyowibowo (2018) di Indonesia. ${ }^{6}$ Dalam studi tersebut sejumlah 132 pasien dengan gejala kanker payudara sebelum adanya diagnosis secara definitif dilaporkan bahwa permasalahan kesehatan yang dialami oleh pasien ialah rasa sakit atau 
Tabel I. Karakteristik pasien Kanker Payudara

\begin{tabular}{|c|c|c|}
\hline $\begin{array}{l}\text { Karakteristik } \\
\text { Pasien }\end{array}$ & $\begin{array}{c}\text { Jumlah pasien Kanker } \\
\text { Payudara }(\mathrm{N}=93)\end{array}$ & $\begin{array}{c}\text { Persentase jumlah pasien } \\
\text { Kanker Payudara (\%) }\end{array}$ \\
\hline \multicolumn{3}{|l|}{ Umur } \\
\hline$<45$ Tahun & 39 & 41,9 \\
\hline$\geq 45$ Tahun & 54 & 58,1 \\
\hline Mean $\pm S D$ & $46,5 \pm 7,25$ & \\
\hline \multicolumn{3}{|l|}{ Pendidikan } \\
\hline SD-SMP & 24 & 25,8 \\
\hline$>$ SMP & 69 & 74,2 \\
\hline \multicolumn{3}{|l|}{ Pekerjaan } \\
\hline Bekerja & 48 & 51,6 \\
\hline IRT & 45 & 48,4 \\
\hline \multicolumn{3}{|l|}{ Status Pernikahan } \\
\hline Belum Menikah & 11 & 11,8 \\
\hline Menikah & 82 & 88,2 \\
\hline \multicolumn{3}{|l|}{ Penghasilan } \\
\hline$\leq 4$ juta & 35 & 37,6 \\
\hline$>4$ juta & 58 & 62,4 \\
\hline \multicolumn{3}{|l|}{ Asuransi } \\
\hline Tidak memiliki asuransi & 2 & 2,2 \\
\hline memiliki asuransi & 91 & 97,8 \\
\hline \multicolumn{3}{|l|}{ Stadium Kanker } \\
\hline 1 & 20 & 21,5 \\
\hline 2 & 44 & 47,3 \\
\hline 3 & 23 & 24,7 \\
\hline 4 & 6 & 6,5 \\
\hline \multicolumn{3}{|l|}{ Gejala } \\
\hline Tidak ada gejala & 22 & 23,7 \\
\hline Ada gejala & 71 & 76,3 \\
\hline \multicolumn{3}{|l|}{ Riwayat penyakit keluarga } \\
\hline \multicolumn{3}{|l|}{ Tidak } \\
\hline \multirow[t]{2}{*}{$\mathrm{Ya}$} & 68 & 73,1 \\
\hline & 25 & 26,9 \\
\hline \multicolumn{3}{|l|}{ Lama menderita } \\
\hline$\leq 2$ Tahun & 65 & 69,9 \\
\hline$>2$ Tahun & 28 & 30,1 \\
\hline
\end{tabular}

ketidaknyamanan dan kecemasan atau depresi.6 Penelitian yang dilakukan oleh Matalqah di Malaysia yang menggunakan instrumen EQ-5D juga dilaporkan bahwa permasalahan kesehatan yang sering terjadi pada pasien kanker payudara adalah rasa sakit atau ketidaknyamanan dan kecemasan atau depresi. ${ }^{18}$

Pada penelitian ini sebanyak 82 pasien kanker payudara menyatakan bahwa tidak kesulitan dalam berjalan, 82 pasien kanker payudara menyatakan tidak kesulitan untuk mandi dan atau berpakaian sendiri, 72 pasien kanker payudara menyatakan tidak kesulitan dalam mengerjakan kegiatan yang biasa dilakukan. Pada domain kecemasan/depresi yang merupakan domain paling banyak dilaporkan banyak permasalahan hanya terdapat 16 pasien kanker payudara yang tidak merasakan cemas atau sedih. Gambaran 
Tabel II. Perbandingan respon domain EQ-5D-5L pasien kanker payudara per-level

\begin{tabular}{|c|c|c|c|c|c|c|c|c|c|c|}
\hline \multirow[t]{2}{*}{ Domain } & \multicolumn{2}{|c|}{$\begin{array}{c}\text { Level } \\
1 \\
\end{array}$} & \multicolumn{2}{|c|}{$\begin{array}{c}\text { Level } \\
2 \\
\end{array}$} & \multicolumn{2}{|c|}{$\begin{array}{c}\text { Level } \\
3 \\
\end{array}$} & \multicolumn{2}{|c|}{$\begin{array}{c}\text { Level } \\
4 \\
\end{array}$} & \multicolumn{2}{|c|}{$\begin{array}{c}\text { Level } \\
5 \\
\end{array}$} \\
\hline & 1 & $\%$ & 2 & $\%$ & 3 & $\%$ & 4 & $\%$ & 5 & $\%$ \\
\hline Mobilitas (MO) & 82 & 88,2 & 10 & 10,7 & 1 & 1,1 & - & - & - & - \\
\hline Perawatan diri (SC) & 82 & 88,2 & 10 & 10,7 & 1 & 1,1 & - & - & - & - \\
\hline $\begin{array}{l}\text { Kegiatan yang biasa } \\
\text { dilakukan (UA) }\end{array}$ & 72 & 77,4 & 19 & 20,4 & 2 & 2,2 & - & - & - & - \\
\hline $\begin{array}{l}\text { Rasa sakit/ } \\
\text { Ketidaknyamanan } \\
\text { (PD) }\end{array}$ & 48 & 51,6 & 33 & 35,5 & 10 & 10,7 & 2 & 2,2 & - & - \\
\hline $\begin{array}{l}\text { Kecemasan/ Depresi } \\
(\mathrm{AD})\end{array}$ & 16 & 17,2 & 60 & 64,5 & 10 & 10,7 & 5 & 5,4 & 2 & 2,2 \\
\hline
\end{tabular}

Tabel III. Perbandingan respon masalah setiap domain EQ-5D-5L pasien kanker payudara

\begin{tabular}{lcccc}
\hline \multicolumn{1}{c}{ Domain } & $\begin{array}{c}\text { Tidak memiliki } \\
\text { masalah kesehatan }\end{array}$ & \% & $\begin{array}{c}\text { Memiliki masalah } \\
\text { kesehatan }\end{array}$ & $\%$ \\
\hline Mobilitas (MO) & 82 & 88,2 & 11 & 11,8 \\
Perawatan diri (SC) & 82 & 88,2 & 11 & 11,8 \\
$\begin{array}{l}\text { Kegiatan yang biasa } \\
\text { dilakukan (UA) }\end{array}$ & 72 & 77,4 & 21 & 22,6 \\
$\begin{array}{l}\text { Rasa sakit/ } \\
\text { Ketidaknyamanan (PD) }\end{array}$ & 48 & 51,6 & 45 & 48,4 \\
Kecemasan/ Depresi (AD) & 16 & 17,2 & 77 & 82,8 \\
\hline
\end{tabular}

perbandingan respon domain EQ-5D-5L per level pada pasien kanker payudara (Tabel II).

Dalam studi ini, peneliti menilai health state pasien kanker payudara. Nilai health state 11111 ialah gambaran untuk kesehatan yang sempurna, dan 55555 adalah gambaran kesehatan terburuk. Dalam penelitian ini diperoleh hasil health state yang beragam. Pasien kanker payudara memiliki 37 health state dengan nilai utility 0,921 - 0,322. Sebanyak 34 pasien kanker payudara $(36,6 \%)$ memiliki health state 11112 yang mana menggambarkan pasien tidak kesulitan dalam berjalan, tidak kesulitan untuk perawatan diri, tidak kesulitan dalam melakukan kegiatan keseharian, tidak merasa sakit atau tidak nyaman, dan merasa sedikit cemas atau depresi. Sejumlah 11 pasien kanker payudara $(11,8 \%)$ diperoleh health state 11122 yang menggambarkan pasien tidak kesulitan dalam berjalan, tidak kesulitan untuk perawatan diri, tidak kesulitan dalam melakukan kegiatan keseharian, tetapi sedikit mengalami sakit atau ketidaknyaman, dan sedikit cemas atau depresi. Variasi gambaran health state pasien kanker payudara (Tabel IV).

Tabel V menggambarkan nilai utility dan VAS pasien kanker payudara, hasil dari penelitian ini adalah nilai utility pasien kanker payudara $0,821 \pm 0,123$. Nilai VAS yang diperoleh ialah $74,41 \pm 11,67$. Nilai utility yang diperoleh memiliki kemiripan terhadap penelitian yang dilakukan oleh Li (2018) di China pada 608 pasien kanker payudara. ${ }^{19}$ Penelitian lain terkait dengan kualitas hidup pasien kanker payudara yang telah dilakukan oleh Rautaulin (2017) menunjukkan nilai utility pasien kanker payudara yang sedikit lebih tinggi dibandingkan hasil penelitian ini $(0,85)$ dan nilai VAS yang berbeda yaitu 76,41. ${ }^{9}$ Penelitian Matalqah (2011) di Penang, Malaysia pada pasien kanker payudara diperoleh nilai EQ-5D dan nilai VAS yang berbeda yaitu 0,71 dan nilai VAS $72,7 .{ }^{18}$ Hasil 
Tabel IV. Gambaran Health State Pasien Kanker Payudara

\begin{tabular}{|c|c|c|c|}
\hline \multicolumn{4}{|c|}{ Pasien Kanker Payudara } \\
\hline Health State & n $(\mathrm{N}=93)$ & Jumlah N (\%) & Utility \\
\hline 11112 & 34 & 36,6 & 0,921 \\
\hline 11113 & 2 & 2,2 & 0,866 \\
\hline 11114 & 1 & 1,1 & 0,773 \\
\hline 11115 & 1 & 1,1 & 0,695 \\
\hline 11121 & 7 & 7,5 & 0,914 \\
\hline 11122 & 11 & 11,8 & 0,835 \\
\hline 11123 & 1 & 1,1 & 0,780 \\
\hline 11124 & 1 & 1,1 & 0,687 \\
\hline 11125 & 1 & 1,1 & 0,609 \\
\hline 11131 & 1 & 1,1 & 0,905 \\
\hline 11132 & 1 & 1,1 & 0,826 \\
\hline 11134 & 2 & 2,2 & 0,678 \\
\hline 11143 & 1 & 1,1 & 0,668 \\
\hline 11211 & 1 & 1,1 & 0,831 \\
\hline 11212 & 3 & 3,2 & 0,831 \\
\hline 11213 & 2 & 2,2 & 0,776 \\
\hline 11221 & 1 & 1,1 & 0,824 \\
\hline 11222 & 2 & 2,2 & 0,745 \\
\hline 11223 & 1 & 1,1 & 0,690 \\
\hline 11232 & 1 & 1,1 & 0,736 \\
\hline 11332 & 1 & 1,1 & 0,670 \\
\hline 12111 & 1 & 1,1 & 0,899 \\
\hline 12113 & 1 & 1,1 & 0,765 \\
\hline 12121 & 1 & 1,1 & 0,813 \\
\hline 12122 & 1 & 1,1 & 0,734 \\
\hline 12232 & 1 & 1,1 & 0,635 \\
\hline 13222 & 1 & 1,1 & 0.605 \\
\hline 21112 & 1 & 1,1 & 0,802 \\
\hline 21121 & 1 & 1,1 & 0,795 \\
\hline 21132 & 1 & 1,1 & 0,707 \\
\hline 21221 & 2 & 2,2 & 0,705 \\
\hline 21222 & 1 & 1,1 & 0,626 \\
\hline 22114 & 1 & 1,1 & 0,553 \\
\hline 22221 & 1 & 1,1 & 0,604 \\
\hline 22233 & 1 & 1,1 & 0,461 \\
\hline 22241 & 1 & 1,1 & 0,492 \\
\hline 32333 & 1 & 1,1 & 0,322 \\
\hline
\end{tabular}

penelitian Matalqah (2011) lebih rendah dibandingkan dengan penelitian ini. ${ }^{18}$ Hashemi (2019) dalam penelitiannya dilaporkan terdapat perbedaan nilai EQ-5D pada pasien kanker payudara. ${ }^{20}$

Pasien dengan usia $<45$ tahun memiliki nilai utility yang lebih rendah dibandingkan dengan pasien kanker payudara dengan usia $\geq 45$ tahun. Abu Farha (2017) dalam penelitian yang dilakukan di palestina menyebutkan bahwa terdapat perbedaan yang signifikan berkaitan dengan gap usia pasien kanker payudara. ${ }^{21}$ Dalam penelitiannya disebutkan bahwa pasien dengan usia lebih muda 
Abdillah Mursyid, et al

Tabel V. Nilai utility dan VAS pasien Kanker Payudara

\begin{tabular}{|c|c|c|c|c|c|c|}
\hline & \multicolumn{3}{|c|}{ EQ-5D } & \multicolumn{3}{|c|}{ VAS } \\
\hline & Utility & (SD) & p-value & score & (SD) & $p$-value \\
\hline Total & 0,821 & 0,123 & & 74,41 & 11,67 & \\
\hline Umur & & & 0,136 & & & 0,167 \\
\hline$<45$ Tahun & 0,799 & 0,138 & & 72,44 & 12,76 & \\
\hline$\geq 45$ Tahun & 0,838 & 0,109 & & 75,83 & 10,71 & \\
\hline Pendidikan & & & 0,926 & & & 0,675 \\
\hline SD-SMP & 0,819 & 0,133 & & 73,54 & 8,78 & \\
\hline$>\mathrm{SMP}$ & 0,822 & 0,121 & & 74,71 & 12,5 & \\
\hline Pekerjaan & & & $0,012^{*}$ & & & 0,952 \\
\hline Bekerja & 0,852 & 0,110 & & 74,48 & 10,68 & \\
\hline IRT & 0,788 & 0,129 & & 74,33 & 12,77 & \\
\hline Status Pernikahan & & & 0,883 & & & $0,049^{*}$ \\
\hline Belum Menikah & 0,827 & 0,127 & & 80,91 & 7,00 & \\
\hline Menikah & 0,821 & 0,123 & & 73,54 & 11,92 & \\
\hline Penghasilan & & & 0,848 & & & $0,044^{*}$ \\
\hline$\leq 4$ juta & 0,818 & 0,126 & & 71,29 & 11,90 & \\
\hline$>4$ juta & 0,823 & 0,123 & & 76,29 & 11,22 & \\
\hline Asuransi & & & 0,614 & & & 0,251 \\
\hline \multirow{2}{*}{$\begin{array}{l}\text { Tidak memiliki asuransi } \\
\text { memiliki asuransi }\end{array}$} & 0,778 & 0,202 & & 65,00 & 21,21 & \\
\hline & 0,822 & 0,123 & & 74,62 & 11,50 & \\
\hline Gejala & & & $0,002^{*}$ & & & 0,227 \\
\hline Tidak ada gejala & 0,892 & 0,043 & & 77,05 & 10,07 & \\
\hline Ada gejala & 0,800 & 0,132 & & 73,59 & 12,07 & \\
\hline Riwayat penyakit keluarga & & & 0,975 & & & 0,135 \\
\hline Tidak & & & & & & \\
\hline \multirow[t]{2}{*}{ Ya } & 0,821 & 0,129 & & 73,31 & 11,79 & \\
\hline & 0,822 & 0,109 & & 77,40 & 11,09 & \\
\hline Lama menderita & & & 0,289 & & & 0,824 \\
\hline$\leq 2$ Tahun & 0,821 & 0,131 & & 74,23 & 11,1 & \\
\hline$>2$ Tahun & 0,842 & 0,103 & & 74,82 & 13,08 & \\
\hline
\end{tabular}

memiliki kualitas hidup yang lebih rendah dibandingkan pada pasien usia tua. ${ }^{21}$ Yfantis (2018), dan Gangane (2017) menyebutkan bahwa pasien kanker payudara dengan usia muda memiliki kualitas hidup yang lebih buruk dibandingkan dengan pasien dengan usia yang lebih tua dikarenakan kecemasan nya terhadap masa depan dan peran nya sebagai ibu. ${ }^{22,23}$ Tetapi, hasil yang berbeda ditunjukkan pada penelitian yang dilakukan oleh Matalqah yang menyebutkan usia muda memiliki utility yang lebih baik $(2011)^{18}$.
Pasien kanker payudara dengan tingkat pendidikan SD-SMP menunjukkan hasil kualitas hidup yang lebih rendah dibandingkan pada pasien dengan tingkat pendidikan $>$ SMP $(p=0,012)$. Penelitian lain menyebutkan bahwa rendah nya tingkat pendidikan dari pasien kanker payudara berhubungan dengan rendahnya kualitas hidup pasien. ${ }^{23}$ Tingkat pendidikan dapat secara langsung mempengaruhi sikap kepedulian seperti Breast-Self Examination (BSE) terhadap perubahan fisik yang terjadi disekitar tubuh nya sehingga dapat 
Tabel VI. Nilai utility dan VAS pasien Kanker Payudara

\begin{tabular}{ccccccc}
\hline & $\begin{array}{c}\text { EQ-5D } \\
\text { utility }\end{array}$ & (SD) & p-value & VAS score & (SD) & $p$-value \\
\hline $\begin{array}{c}\text { Stadium } \\
\text { Kanker }\end{array}$ & & & $0,027^{*}$ & & & 0,613 \\
1 & 0,845 & 0,119 & & 75,25 & 9,66 & \\
2 & 0,848 & 0,105 & & 74,43 & 10,95 & \\
3 & 0,762 & 0,143 & & 75,22 & 13,60 & \\
4 & 0,773 & 0,112 & & 68,33 & 16,02 & \\
\hline
\end{tabular}

mendeteksi lebih dini terhadap kejadian kanker. ${ }^{24,25}$

Pasien kanker payudara yang bekerja (nilai utility $=0,852$ ) mempunyai kualitas hidup lebih baik dibandingkan dengan pasien kanker payudara yang tidak bekerja/IRT (nilai utility $=0,788$ ). Dari hasil uji independent t-test menunjukan hasil yang signifikan terdapat perbedaan $(\mathrm{p}=0,012)$. Nilai utility berdasarkan status pernikahan, menunjukkan bahwa pasien kanker payudara yang belum menikah (nilai utility $=0,827$ ) memiliki nilai utility lebih baik dibandingkan dengan pasien yang menikah (nilai utility $=0,821$ ), tetapi secara statistik tidak menunjukan perbedaan. Hasil ini berbeda dengan studi yang telah dilakukan oleh Gangane (2017), dalam studi nya disebutkan bahwa pasien yang belum menikah berhubungan dengan menurunnya kualitas hidup pasien kanker payudara. ${ }^{23}$ Penelitian lain menyebutkan bahwa memiliki pasangan/menikah berpengaruh positif terhadap kualitas hidup yang lebih baik jika dibandingkan dengan pasien kanker payudara yang berstatus sendiri atau tidak menikah. ${ }^{21}$

Pada penelitian ini, penghasilan memiliki pengaruh pada kualitas hidup pasien kanker payudara. Pasien kanker payudara dengan penghasilan $>4$ juta $(0,823)$ memiliki kualitas hidup yang lebih baik dibandingkan dengan pasien berpenghasilan $\leq 4$ juta $(0,818)$. Al Jabi (2018) menuturkan dalam penelitiannya bahwa semakin besar penghasilan berbanding lurus dengan meningkatknya kualitas hidup pasien. ${ }^{26}$ Penelitian yang dilakukan oleh Setyowibowo (2018) menyebutkan bahwa pasien dengan penghasilan rendah memiliki hubungan terhadap penurunan kualitas hidup. ${ }^{6}$

Gejala yang dirasakan pada pasien kanker payudara juga turut mempengaruhi kualitas hidup pasien. Nilai utility pasien yang merasakan gejala (nilai $u$ tility $=0,800$ ) memiliki kualitas hidup yang lebih rendah dibandingkan dengan pasien kanker payudra yang tidak merasakan gejala (nilai utility = 0,892). Hasil uji menunjukan terdapat perbedaan yang signifikan $(p=0,002)$.

Pada Tabel VI Nilai utility pasien dengan stadium kanker 3 dan $4(0,762) ;(0,773)$ menunjukan nilai utility yang lebih rendah dibandingkan pasien kanker stadium awal (stadium kanker 1 dan 2). Hasil uji SPSS menggunakan independent t-test menunjukkan hasil terdapat perbedaan stadium kanker dapat mempengaruhi nilai utility pasien kanker payudara $(p=0,027)$. Shi (2016) pada penelitiannya di China melaporkan hasil utility akan memburuk seiring dengan keparahan kanker payudara. ${ }^{27}$

Uji multivariate regresi linear berganda menunjukkan bahwa pekerjaan, gejala dan stadium kanker merupakan faktor yang berpengaruh terhadap kualitas hidup pasien kanker payudara di kota Denpasar. Gejala merupakan faktor yang memiliki pengaruh yang paling besar terhadap kualitas hidup pasien $(-0,083)$. Pekerjaan, gejala dan stadium kanker secara simultan berpengaruh terhadap kualitas hidup pasien sebesar 20,5\% ( $p=0,000)$. Hasil uji multivariate regresi berganda dapat dilihat pada Tabel VII.

Keterbatasan dalam penelitian ini adalah total jumlah sampel penelitian ini yang relatif kecil, lokasi pengambilan sampel hanya 
Abdillah Mursyid, et al

Tabel VII. Hasil correlation dan multivariate regresi nilai utility EQ-5D

\begin{tabular}{lcccccc}
\hline Variabel & $\mathbf{R}$ & SE & B & Beta & t & p-value \\
\hline Pekerjaan & $-0,367$ & 0,024 & $-0,050$ & $-0,205$ & -2.145 & 0,035 \\
Gejala & $-0,353$ & 0,028 & $-0,083$ & $-0,288$ & -3.016 & 0,003 \\
Stadium Kanker & $-0,297$ & 0,014 & $-0,035$ & $-0,234$ & -2.472 & 0,015 \\
Constant score & \multicolumn{2}{c}{0.063} & 1,118 & 17.641 & 0.000 \\
& $\mathrm{R}=0,452 ; \mathrm{R}^{2}=0,205 ; \mathrm{R}^{2} \mathrm{Adj}=0,178 ; \mathrm{F}=7.632 ; p$-value $=0.000$ \\
\hline
\end{tabular}

dipilih dari beberapa kanker payudara yang berada di kota Denpasar dan variabel yang digunakan belum mencerminkan secara keseluruhan kondisi klinik pasien sehingga hasil yang didapatkan dinilai kurang sempurna. Penelitian selanjutnya diharapkan dapat menganalisa lebih dalam dengan melihat pengaruh pada tiap variabel, serta menggunakan instrumen spesifik terhadap kanker agar hasil yang didapatkan lebih baik dan komprehensif.

\section{KESIMPULAN}

Kualitas hidup pasien kanker payudara di kota Denpasar menunjukkan nilai utility

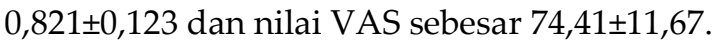
Domain kecemasan/depresi (82,8\%) dan domain rasa sakit/ketidaknyamanan $(48,4 \%)$ merupakan domain yang dilaporkan merupakan masalah kesehatan yang paling banyak terjadi pada pasien kanker payudara. Pekerjaan $(p=0,012)$, gejala $(p=0,002)$, dan stadium kanker $(p=0,027)$ merupakan karakteristik yang berpengaruh terhadap kualitas hidup pasien kanker payudara sebesar $20,5 \%$.

\section{UCAPAN TERIMA KASIH}

Penulis menghanturkan terima kasih kepada para responden pasien kanker payudara di kota Denpasar yang telah berkenan untuk ikut terlibat dalam penelitian ini. Studi ini merupakan bagian dari penelitian tesis Abdillah Mursyid pada Magister Manajemen Farmasi Fakultas Farmasi UGM.

\section{DAFTAR PUSTAKA}

1. Bray F., Ferlay J., Soerjomataram I., Siegel RL., Torre LA., Jemal A. Global cancer statistics 2018: GLOBOCAN estimates of incidence and mortality worldwide for 36 cancers in 185 countries. CA Cancer J Clin. 2018;68(6):394-424.

2. Kementerian Kesehatan Republik Indonesia. Riset Kesehatan Dasar. 2013.

3. Canário ACG., Cabral PUL., Paiva LC de, Florencio GLD, Spyrides MH, Gonçalves AK da S. Physical activity, fatigue and quality of life in breast cancer patients. Rev Assoc Médica Bras. 2016;62(1):38-44.

4. Ataollahi Mr., Sharifi J., Paknahad MR. Breast cancer and associated factors: A review. J Med Life. 2015;8(4):6.

5. Chen Q., Li S., Wang M., Liu L., Chen G. Health-Related Quality of Life among Women Breast Cancer Patients in Eastern China. BioMed Res Int. 2018;2018:1-12.

6. Setyowibowo H., Purba FD., Hunfeld JAM., et al., Quality of life and health status of Indonesian women with breast cancer symptoms before the definitive diagnosis: A comparison with Indonesian women in general. Lin C-Y, ed. PLOS ONE. 2018;13(7):e0200966.

7. Devlin NJ., Brooks R. EQ-5D and the EuroQol Group: Past, Present and Future. Appl Health Econ Health Policy. 2017;15(2):127-137.

8. Devlin NJ., Krabbe PFM. The development of new research methods for the valuation of EQ-5D-5L. Eur J Health Econ. 2013;14(Suppl 1):1-3.

9. Rautalin M., Färkkilä N., Sintonen H., et al., Health-related quality of life in different states of breast cancer comparing different instruments. Acta Oncol. 2018;57(5):622-628. 
10. Kimman ML., Dirksen CD., Lambin P., Boersma LJ. Responsiveness of the EQ$5 \mathrm{D}$ in breast cancer patients in their first year after treatment. Health Qual Life Outcomes. 2009;7(1). doi:10.1186/14777525-7-11

11. Rukminingsih F., Andayani TM., Rahmawati F., Widayati K. HEALTHRELATED QUALITY OF LIFE IN EARLY BREAST CANCER PATIENTS WITH HORMONE RESPONSIVE. Int J Pharm Pharm Sci. December 2018:47-49.

12. Purba FD., Hunfeld JAM., Iskandarsyah A., et al., The Indonesian EQ-5D-5L Value Set. PharmacoEconomics. 2017;35(11):1153-1165.

13. Kementerian Kesehatan Republik Indonesia. InfoDATIN "Bulan Peduli Kanker Payudara." Indonesia; 2016:1-12.

14. Sugiyono. Metode Penelitian Pendidikan: Pendekatan Kuantitatif, Kualitatif Dan $R$ ED. Bandung: Alfabeta; 2010.

15. Ganesh S., Lye M-S., Lau FN. Quality of Life among Breast Cancer Patients In Malaysia. Asian Pac J Cancer Prev. 2016;17(4):1677-1684.

16. Chen H., Zhou M., Tian W., Meng K., He H. Effect of Age on Breast Cancer Patient Prognoses: A Population-Based Study Using the SEER 18 Database. Coleman WB, ed. PLOS ONE. 2016;11(10):e0165409.

17. Wang K., Li X., Zhou C., Ren Y., Wang X-B., He J-J. Socio-economic Factors Influencing Tumor Presentation and Treatment Options in Chinese Breast Cancer Patients. Asian Pac J Cancer Prev. 2013;14(1):267-274.

18. Matalqah LM., Radaideh KM., Yusoff ZM., Awaisu A. Health-related quality of life using EQ-5D among breast cancer survivors in comparison with agematched peers from the general population in the state of Penang, Malaysia. J Public Health. 2011;19(5):475480.

19. Li S., Wang M., Liu L., Chen G. Which approach is better in eliciting health state utilities from breast cancer patients? Evidence from mainland China: XXXX. Eur J Cancer Care (Engl). 2019;28(2):e12965.

20. Hashemi S-M., Balouchi A., Al-Mawali A., et al., Health-related quality of life of breast cancer patients in the Eastern Mediterranean region: A systematic review and meta-analysis. Breast Cancer Res Treat. 2019;174(3):585-596.

21. Abu Farha NH, Khatib MT., Salameh H., Zyoud SH. Cancer-related posttreatment pain and its impact on healthrelated quality of life in breast cancer patients: A cross sectional study in Palestine. Asia Pac Fam Med. 2017;16(1).

22. Yfantis A., Intas G., Tolia M., et al., Health-related quality of life of young women with breast cancer. Review of the literature. JBUON. 2018;23:6.

23. Gangane N., Khairkar P., Hurtig A-K., Sebastián MS. Quality of Life Determinants in Breast Cancer Patients in Central Rural India. Asian Pac J Cancer Prev. 2017;(12).

24. Sani A., Naab F., Aziato L. Influence of educational level on knowledge and practice of breast self-examination among women in Sokoto, Nigeria. J Basic Clin Reprod Sci. 2016;5(2):100.

25. Gurdal SO., Saracoglu GV., Oran ES., Yankol Y., Soybir GR. The Effects of Educational Level on Breast Cancer Awareness: A Cross-Sectional Study in Turkey. Asian Pac J Cancer Prev. 2012;13(1):295-300.

26. Al-Jabi SW., Yahya R., Salameh R., et al., Health-related quality of life in patients with breast cancer in Palestine: An assessment of a cross-sectional study using the EuroQoL-5 dimensions scale. The Lancet. 2018;391:S34.

27. Shi J-F., Huang H-Y., Guo L-W., et al., Quality-of-life and health utility scores for common cancers in China: A multicentre cross-sectional survey. The Lancet. 2016;388:S29. 